\title{
Association of single nucleotide polymorphisms in the fatty acid synthase, LOC514211, and fat mass and obesity-associated genes with milk traits in Indonesian-Holstein dairy cattle
}

\author{
Amalia Puji Rahayu ${ }^{1,2}$, Tety Hartatik ${ }^{3}$, Agung Purnomoadi ${ }^{1}$ and Edy Kurnianto ${ }^{1}$
}

1. Department of Animal Science, Faculty of Animal and Agricultural Sciences, Diponegoro University, Semarang 50275 , Indonesia; 2. Agriculture, Fisheries and Food Center of Semarang Regency, Ungaran 50514, Indonesia; 3. Department of Animal Breeding and Reproduction, Faculty of Animal Sciences, Universitas Gadjah Mada, Yogyakarta 55281, Indonesia.

Corresponding author: Edy Kurnianto, e-mail: kurniantoedy17@gmail.com

Co-authors: APR: amaliapujirahayu.kabsmg@gmail.com, TH: tety@ugm.ac.id, AP: agung194@yahoo.com

Received: 13-05-2019, Accepted: 25-06-2019, Published online: 30-07-2019

doi: 10.14202/vetworld.2019.1160-1166 How to cite this article: Rahayu AP, Hartatik T, Purnomoadi A, Kurnianto E (2019) Association of single nucleotide polymorphisms in the fatty acid synthase, LOC514211, and fat mass and obesity-associated genes with milk traits in Indonesian-Holstein dairy cattle, Veterinary World, 12(7): 1160-1166.

\begin{abstract}
Aim: The study aimed to identify fatty acid synthase (FASN), LOC514211, and fat mass and obesity-associated (FTO) gene polymorphisms and to investigate their associations with milk traits in an Indonesian-Holstein dairy cow population.

Materials and Methods: A total of 100 Indonesian-Holstein cows consisting of 50 heads ( $0^{\text {th }}$ generation; $\mathrm{G}_{0}$ ) and 50 heads of their daughters $\left(1^{\text {st }}\right.$ generation; $\left.G_{1}\right)$ were used. Polymerase chain reaction-restriction fragment length polymorphism was performed to genotype three single nucleotide polymorphisms: rs41919985 in the FASN gene, rs42688595 in the LOC514211 gene, and g.1371T $>$ A in the FTO gene.
\end{abstract}

Results: FASN rs41919985 was associated with milk protein percentage $(p<0.05)$, FTO g.1371T $>$ A was associated with milk fat percentage $(\mathrm{p}<0.05)$, and LOC514211 rs42688595 was not associated with any trait $(\mathrm{p}>0.05)$. Heterozygote variants showed a higher protein percentage for FASN and the highest fat percentage for FTO. These associations were consistent in the $\mathrm{G}_{0}$ and $\mathrm{G}_{1}$ populations.

Conclusion: Our results indicate that the milk protein and fat percentages can be improved by increasing the frequency of the AG genotype of FASN and the AT genotype of FTO, respectively.

Keywords: fat mass and obesity-associated, fatty acid synthase, Indonesian-Holstein cattle, LOC514211, milk traits.

\section{Introduction}

At present, dairy farmers are concerned with not only the milk yield but also the milk quality [1] because it affects the selling price to the milk processing industry. One method used to improve milk quality is to increase the genetic quality of cattle through selection [2]. For conventional selection, it is necessary to have the records of the parents and offspring. On the contrary, when phenotypic data are not available, genomic selection can be used to predict each individual's genomic value, which can shorten generation intervals [3]. Schaeffer [4] stated that genomic selection can increase the efficiency of genetic gains per year by up to $50 \%$ and reduce $92 \%$ of the operational costs for progeny testing. Furthermore, a single nucleotide polymorphism (SNP) at the DNA level can be used for marker-assisted selection to select cattle with superior qualities [5].

Considering the benefits of genomic selection, it is very important to identify the SNPs in

Copyright: Rahayu, et al. Open Access. This article is distributed under the terms of the Creative Commons Attribution 4.0 International License (http://creativecommons.org/licenses/ by/4.0/), which permits unrestricted use, distribution, and reproduction in any medium, provided you give appropriate credit to the original author(s) and the source, provide a link to the Creative Commons license, and indicate if changes were made. The Creative Commons Public Domain Dedication waiver (http:// creativecommons.org/publicdomain/zero/1.0/) applies to the data made available in this article, unless otherwise stated. candidate genes responsible for milk traits. The fatty acid synthase (FASN), LOC514211, and fat mass and obesity-associated (FTO) genes are located on chromosomes 19, 13, and 18, respectively, in bovines. The FASN gene plays a role in fatty acid synthesis in the malonyl-coenzyme a pathway [6], while the FTO gene regulates the neurotrophin signaling pathway in the formation of milk fat [7]. The role of LOC514211 has not been definitively determined, but Anggraeni et al. [8] found that this gene was associated with milk fat yield. Therefore, these genes were chosen as candidate genes and were predicted to be associated with milk traits, especially milk fat yield. Research on the FASN gene has produced inconsistent results. FASN rs41919985 (which is the same as FASNg.17924A > G) was reported to affect milk fat content in the study by Schennink et al. [9], but no effect was found on in a study by Matsumoto et al. [10]. Meanwhile, there has been limited research on the other candidate genes, LOC514211 and FTO. Research on the FTO gene has mostly been conducted in humans [11,12] and meat livestock $[13,14]$, with few studies in dairy cattle [7]. The SNP in the FTO gene analyzed in this study (which is the same as FTOg.12550T $>$ A) was a novel SNP identified by Chung [14] in Hanwoo (Korean cattle). In Indonesian-Holstein cattle, some genetic markers have been studied [15-17], but to 
date, there have been no reports on the three candidate genes selected for the present study. Moreover, most studies on SNP markers only used individual records of dams without confirmation in the next generation $[8,18]$. Previous studies on various genetic markers have produced very different results in various populations. For example, in the study by Maylinda [15], a gene polymorphism in an imported Holstein cow population was significantly associated with milk traits, while the polymorphism in a local Holstein cow population was not, although the analyses were conducted in the same area. Therefore, different polymorphisms may be found in different generations, and their effects on milk traits can also be different.

Based on this background information, for an SNP to be considered a strong genetic marker, it is necessary to confirm its association in the parents $\left(0^{\text {th }}\right.$ generation; $\left.\mathrm{G}_{0}\right)$ and their daughters $\left(1^{\text {st }}\right.$ generation; $\mathrm{G}_{1}$ ). This study was designed to identify polymorphisms in the FASN, LOC514211, and FTO genes and to investigate their associations with milk traits in Indonesian-Holstein dams and their daughters.

\section{Materials and Methods}

\section{Ethical approval}

The protocol was carried out according to the standard rule of animal treating as appointed in the Republic of Indonesia's law, number 41, 2014, as regard husbandry and animal health. This study was approved by Animal Ethics Committee in Faculty of Animal and Agricultural Sciences, Diponegoro University, Indonesia.

\section{Study area}

This study was performed at the Baturraden Cattle Breeding and Forage Centre (BBPTUHPT Baturraden), Purwokerto, Central Java, Indonesia. DNA analyses were conducted at the Laboratory of Animal Breeding and Genetics, Universitas Gadjah Mada, Yogyakarta, Indonesia.

\section{Data collection}

In this study, we focused on two generations on the same farm; thus, the availability of samples was limited. We used 100 samples (50 pairs of $\mathrm{G}_{0}-\mathrm{G}_{1} ; \mathrm{G}_{1}$ was the daughter of $G_{0}$ ) that were still available on the farm and met the criteria of having individual first lactation milk yield and milk composition records. In fact, other studies on gene association and polymorphism used smaller sample sizes [16,19-21]. DNA from the samples was isolated from cow tail vein blood using a DNA Extraction Kit $\left(\mathrm{gSYNC}^{\mathrm{TM}}\right.$, Geneaid, Taiwan) following the manufacturer's protocol. The studied parameters were milk fat percentage, total milk yield, milk fat yield (=fat $\% \times$ milk yield), milk protein percentage, and milk protein yield (=protein $\% \times$ milk yield).

\section{DNA amplification and genotyping}

Based on the Holstein cattle DNA sequence in GenBank, three primer pairs were applied to amplify fragments of the candidate genes (FASN, LOC514211, and FTO) (Table-1) $[8,18]$. These candidate genes were selected as markers because they are involved in fat synthesis [6-8]. Because milk fat has a genetic correlation with milk yield and milk protein [22], these candidate genes were also used to assess these traits. The polymerase chain reaction (PCR) protocol was performed in a $25 \mu \mathrm{L}$ volume, including $2 \mu \mathrm{L}$ genomic DNA, forward and reverse primers $(0.5 \mu \mathrm{L}$ each), $12.5 \mu \mathrm{L}$ MyTaq HS Red Mix (Bioline, UK), and $9.5 \mu \mathrm{L}$ double-distilled water $\left(\mathrm{ddH}_{2} \mathrm{O}\right)$. The following program was used on a PCR machine (Advanced Primus 25, Peqlab, Germany): Predenaturation at $94^{\circ} \mathrm{C}$ for 5-10 min followed by 34-36 cycles consisting of denaturation at $94^{\circ} \mathrm{C}$ for $30 \mathrm{~s}$; annealing at $60^{\circ} \mathrm{C}$ for $30 \mathrm{~s}$ for FASN, at $58.8^{\circ} \mathrm{C}$ for $45 \mathrm{~s}$ for LOC514211, or at $57^{\circ} \mathrm{C}$ for $20 \mathrm{~s}$ for $\mathrm{FTO}$; extension at $72^{\circ} \mathrm{C}$ for $30-60 \mathrm{~s}$; and a final extension at $72^{\circ} \mathrm{C}$ for $5-25 \mathrm{~min}$. The products were analyzed using the restriction fragment length polymorphism (RFLP) method and first digested using restriction enzymes (Thermo Scientific, USA) in a $15 \mu \mathrm{L}$ volume consisting of $4 \mu \mathrm{L}$ PCR product; $1.5 \mu \mathrm{L}$ buffer; $0.5 \mu \mathrm{L}$ MscI for FASN, $0.3 \mu \mathrm{L}$ TaqI for LOC 514211 , or $0.3 \mu \mathrm{L}$ HpyCH4III for FTO; and $\mathrm{ddH}_{2} \mathrm{O}$ to the final volume. They were incubated at $37^{\circ} \mathrm{C}$ for $2 \mathrm{~h}$ for FASN or at $65^{\circ} \mathrm{C}$ for $3 \mathrm{~h}$ for LOC514211 and FTO $[8,14,18]$. The digested results were examined on a $3 \%$ agarose gel (stained with ethidium bromide) after $1 \mathrm{~h}$ of electrophoresis $(50 \mathrm{~V})$ in $\times 1$ Tris-borate-EDTA buffer. The fragments were compared with a 50 bp DNA ladder (HyperLadder ${ }^{\mathrm{TM}}$, Bioline, UK). The representative results of each genotype were sequenced by PT. Genetika Science, Jakarta.

\section{Statistical analysis}

The allele and genotype frequencies were analyzed using the Chi-square test [17]. The general linear model procedure in the Statistical Package for the Social Sciences (SPSS) version 20 (IBM, USA) was performed to verify the association of the SNPs with traits as follows: $\mathrm{Y}_{\mathrm{ij}}=\mu+\tau_{\mathrm{i}}+\varepsilon_{\mathrm{ij}}$, where $\mathrm{Y}_{\mathrm{ij}}=$ The analyzed trait, $\mu=$ General mean, $\tau_{i}=i^{\text {th }}$ genotype effect, and $\varepsilon_{\mathrm{ij}}=$ Random error effect. The $\mathrm{G}_{0}$ and $\mathrm{G}_{1}$ trait performances were compared using t-test. Environment factors were not included in the model because (1) $G_{0}$ and $\mathrm{G}_{1}$ were similarly managed on the same farm, (2) the milk yield was corrected for the calving age using a correction factor [23], and (3) there were no extreme seasonal changes. Note that, the similar environment had little effect on the production traits (correlation value 0.14), and Vanvleck and Barr [24] and Mulder et al. [25] stated that when studying quantitative genetics, it could be assumed that the environmental variances among contemporary groups (e.g., calving year-season) could be ignored.

\section{Results}

\section{Allele frequencies of the SNPs}

The polymorphisms detected in PCR-RFLP fragments of the Indonesian-Holstein FASN, 
Table-1: Primer pairs used to amplify gene fragments.

\begin{tabular}{|c|c|c|c|c|}
\hline Gene & Primer $\left(5^{\prime} \rightarrow 3^{\prime}\right)$ & $\begin{array}{l}\text { PCR product } \\
\text { size (bp) }\end{array}$ & $\begin{array}{c}\text { GenBank } \\
\text { accession No. }\end{array}$ & References \\
\hline FASN & $\begin{array}{l}\mathrm{F}=\mathrm{AGAGCTGACGGACTCCACAC} \\
\mathrm{R}=\mathrm{CTGCATGAAGAAGCACATGG}\end{array}$ & 697 & AF285607 & {$[18]$} \\
\hline LOC 514211 & $\begin{array}{l}\mathrm{F}=\mathrm{ACGGTGTTGGGTTCCTG} \\
\mathrm{R}=\mathrm{CTGTCTTGCCCTGTTCG}\end{array}$ & 352 & rs42688595 & {$[8]$} \\
\hline FTO & $\begin{array}{l}\mathrm{F}=\text { TGCAAAGTACAATGAGGCCG } \\
\mathrm{R}=\text { CCCCATGCCAAAATACGGTT }\end{array}$ & 301 & HM777022 & Designed by Primer 3 software \\
\hline
\end{tabular}

$\mathrm{PCR}=$ Polymerase chain reaction, FASN=Fatty acid synthase, $\mathrm{FTO}=$ Fat mass and obesity-associated, F=Forward, $\mathrm{R}=$ Reverse

LOC514211, and FTO genes are shown in Figure-1. There were only two FASN rs41919985 genotypes found in this study, GG (342 bp/355 bp) and AG (167 bp/188 bp/342 bp/355 bp), while three genotypes each were found for LOC514211 rs42688595, AA (334 bp), CC (97 bp/237 bp), and AC (97 bp/237 bp/334 bp), and FTO g.1371T >A, AA $(285 \mathrm{bp})$, TT $(70 \mathrm{bp} / 215 \mathrm{bp})$, and AT (70 bp/215 bp/285 bp).

The genotype and allele frequencies of the SNPs are presented in Table-2. The G allele frequency of FASN rs41919985 was higher than the A allele frequency. $\mathrm{G}_{0}$ contained $79 \% \mathrm{G}$ allele and $21 \% \mathrm{~A}$ allele, whereas $\mathrm{G}_{1}$ contained $84 \% \mathrm{G}$ allele and $26 \%$ A allele. The frequency of the $\mathrm{C}$ allele (0.51) of LOC514211 rs42688595 was higher than the frequency of the $\mathrm{A}$ allele (0.49). CC was the most frequent genotype (0.42), followed by AA (0.39) and AC (0.19). The most common genotype of FTO g.1371T $>$ A was the AA genotype.

\section{Association of the SNPs with milk traits}

As shown in Table-3, FASN rs41919985 was associated with the milk protein percentage $(\mathrm{p}=0.002$ 0.048). Milk produced from the GG genotype was characterized by a lower protein percentage $(2.90 \%)$ than milk produced from the AG genotype (3.08\%). As shown in Table-4, LOC514211 rs4268859 did not affect the studied traits. As presented in Table-5, FTO g. $1371 \mathrm{~T}>\mathrm{A}$ was associated with fat percentage. Cows with the AT genotype had a significantly higher fat percentage (4.41-4.74\%) than cows with the TT genotype (3.17-3.92\%). As shown in Table-6, the milk fat and protein percentages of $\mathrm{G}_{1}(3.81 \%$ and $2.87 \%$, respectively) were lower than those of $\mathrm{G}_{0}(4.50 \%$ and $3.00 \%$, respectively).

\section{Discussion}

\section{Allele frequencies of the SNPs}

The genotypes were determined in this study by observing the DNA bands. Different fragments were obtained because if a nucleotide base undergoes a mutation, the cutting location for a restriction enzyme will change, so an enzyme might cut normal DNA fragments and mutated DNA fragments in different places [15]. Thus, after the mutation, the fragments formed will be different from the fragments produced with normal DNA.

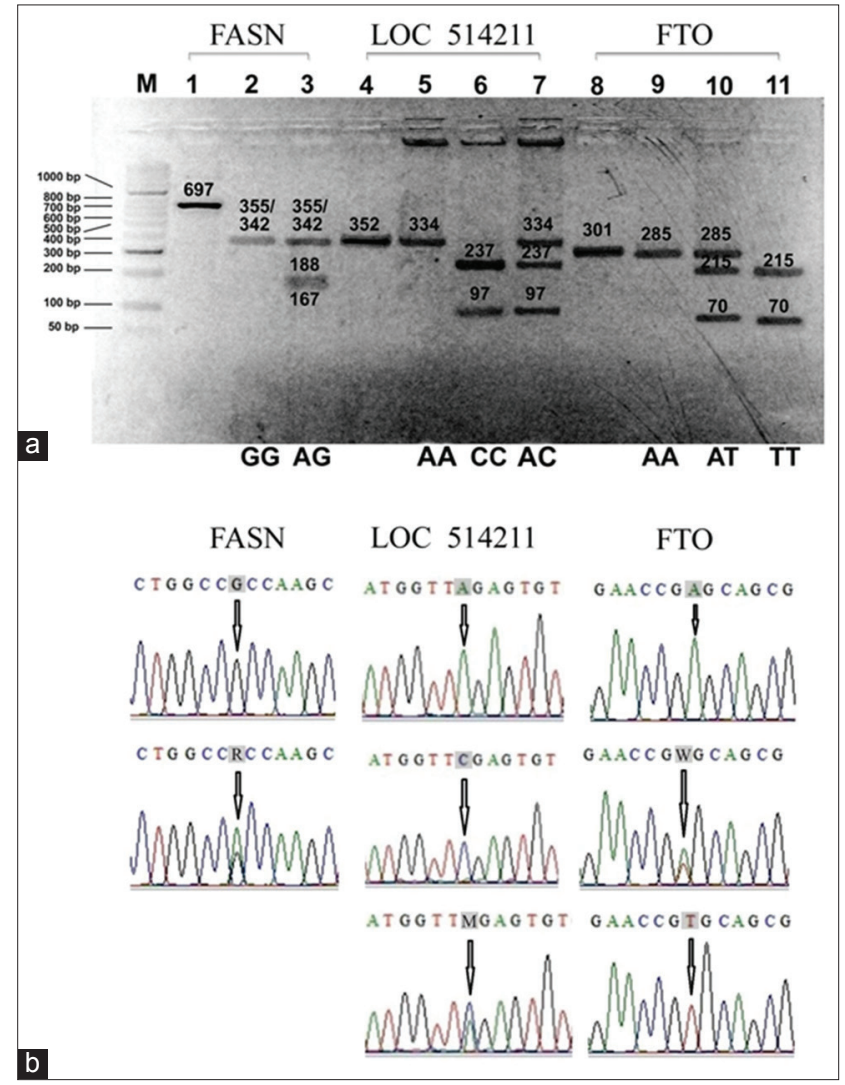

Figure-1: Representative results of polymerase chain reaction-restriction fragment length polymorphism (PCRRFLP) following (a) electrophoresis. All numbers in the box in units of bp. M: 50 bp DNA marker; 1, 4, and 8: PCR products; 2-3: PCR-RFLP FASN-MscI; 5-7: PCR-RFLP LOC514211-TaqI; 9-11: PCR-RFLP FTO-HPYCH4III; (b) sequencing. Shaded letters indicate single nucleotide polymorphism positions in chromatograms. $\mathrm{R}=\mathrm{G}$ or $\mathrm{A}, \mathrm{M}=\mathrm{A}$ or $\mathrm{C}, \mathrm{W}=\mathrm{A}$ or $\mathrm{T}$.

FASN rs41919985 in the population studied was polymorphic with two genotypes, namely, AG and GG. Different from the results of this study, in which the AA genotype was not found, a previous study found three genotypes (GG, AG, and AA), but the AA genotype only appears at a low frequency of 0.06 in Turkey Anatolian Red cattle [26] and 0.08 in Chinese Holstein cattle and Fleckvieh bulls [18,27]. The AA genotype was reported at a higher frequency (0.28) in Dutch Holstein cattle [9]. Thus, the absence of AA genotypes in this study was not because the AA genotype is lethal but probably because the $\mathrm{G}$ allele is a common allele in various populations. Six samples of frozen bull semen that had been used (the sires of $\mathrm{G}_{1}$ ) 
Table-2: Genotype and allele frequencies of SNPs.

\begin{tabular}{|c|c|c|c|c|c|c|c|c|}
\hline \multirow[t]{2}{*}{ SNP } & \multirow[t]{2}{*}{ Generation } & \multirow[t]{2}{*}{$\mathbf{n}$} & \multicolumn{3}{|c|}{ Genotypes } & \multicolumn{2}{|c|}{ Alleles } & \multirow[t]{2}{*}{$\chi^{2}$ test } \\
\hline & & & AA & AG & GG & $\mathbf{A}$ & G & \\
\hline FASN & $\mathrm{G}_{0}$ & 50 & 0.00 & 0.42 & 0.58 & 0.21 & 0.79 & $E\left(\chi^{2}=3.53\right)$ \\
\hline \multirow[t]{3}{*}{ rs41919985 } & $\mathrm{G}_{1}$ & 50 & 0.00 & 0.32 & 0.68 & 0.16 & 0.84 & $E\left(\chi^{2}=1.81\right)$ \\
\hline & All samples & 100 & 0.00 & 0.37 & 0.63 & 0.19 & 0.81 & \\
\hline & & & AA & $A C$ & $\mathrm{CC}$ & A & C & \\
\hline LOC514211 & $\mathrm{G}_{0}$ & 50 & 0.38 & 0.20 & 0.42 & 0.48 & 0.52 & $\mathrm{D}\left(\chi^{2}=17.96\right)$ \\
\hline \multirow[t]{3}{*}{ rs42688595 } & $\mathrm{G}_{1}$ & 50 & 0.40 & 0.18 & 0.42 & 0.49 & 0.51 & $D\left(\chi^{2}=20.47\right)$ \\
\hline & All samples & 100 & 0.39 & 0.19 & 0.42 & 0.49 & 0.51 & \\
\hline & & & $\mathrm{AA}$ & AT & Tा & A & $\mathrm{T}$ & \\
\hline FTO & $\mathrm{G}_{0}$ & 50 & 0.72 & 0.22 & 0.06 & 0.83 & 0.17 & $E\left(\chi^{2}=2.43\right)$ \\
\hline \multirow[t]{2}{*}{ g. $1367 \mathrm{~A}>\mathrm{T}$} & $\mathrm{G}_{1}$ & 50 & 0.86 & 0.08 & 0.06 & 0.90 & 0.10 & $D\left(\chi^{2}=15.43\right)$ \\
\hline & All samples & 100 & 0.79 & 0.15 & 0.06 & 0.87 & 0.13 & \\
\hline
\end{tabular}

FASN=Fatty acid synthase, $\mathrm{FTO}=$ Fat mass and obesity-associated, $\mathrm{n}=$ The number of samples, $\mathrm{G}_{0}=0^{\text {th }}$ generation, $\mathrm{G}_{1}=1^{\text {st }}$ generation, All samples $=$ Both $\mathrm{G}_{0}$ and $\mathrm{G}_{1}, \mathrm{D}=$ Disequilibrium $\left(\chi^{2}>\chi^{2}\right.$ table $), \mathrm{E}=$ Equilibrium $\left(\chi^{2}<\chi^{2}\right.$ table $)$, $\chi^{2}$ table $_{(0,05 ; \mathrm{df}=1)}=3,841, \mathrm{SNP}=$ Single nucleotide polymorphism

Table-3: Association of FASN rs41919985 with milk traits.

\begin{tabular}{|c|c|c|c|c|c|c|}
\hline \multirow[t]{3}{*}{ Parameter } & \multirow[t]{3}{*}{ Generation } & \multicolumn{4}{|c|}{ Genotype } & \multirow[t]{3}{*}{ p-value } \\
\hline & & \multicolumn{2}{|r|}{ GG } & \multicolumn{2}{|r|}{ AG } & \\
\hline & & $\mathbf{n}$ & $\mathbf{Y} \pm$ SEM & $\mathbf{n}$ & $\mathbf{Y} \pm$ SEM & \\
\hline \multirow[t]{3}{*}{ Milk yield $(x 1000 \mathrm{~kg})$} & $\mathrm{G}_{0}$ & 29 & $4.17 \pm 0.23$ & 21 & $3.63 \pm 0.29$ & 0.146 \\
\hline & & 34 & $4.01 \pm 0.23$ & 16 & $4.25 \pm 0.38$ & 0.579 \\
\hline & All samples & 63 & $4.09 \pm 0.16$ & 37 & $3.90 \pm 0.24$ & 0.496 \\
\hline \multirow[t]{3}{*}{ Fat (\%) } & $\mathrm{G}_{0}$ & 29 & $4.46 \pm 0.13$ & 21 & $4.57 \pm 0.08$ & 0.519 \\
\hline & $\mathrm{G}_{1}$ & 34 & $3.63 \pm 0.12$ & 16 & $3.89 \pm 0.11$ & 0.167 \\
\hline & All samples & 63 & $4.05 \pm 0.09$ & 37 & $4.22 \pm 0.10$ & 0.451 \\
\hline \multirow[t]{3}{*}{ Fat yield (kg) } & $\mathrm{G}_{0}$ & 29 & $184.56 \pm 11.03$ & 21 & $163.66 \pm 12.19$ & 0.214 \\
\hline & $\mathrm{G}_{1}$ & 34 & $155.00 \pm 9.43$ & 16 & $152.20 \pm 13.15$ & 0.866 \\
\hline & All samples & 63 & $168.61 \pm 7.37$ & 37 & $158.71 \pm 8.88$ & 0.403 \\
\hline \multirow[t]{3}{*}{ Protein (\%) } & $\mathrm{G}_{0}$ & 29 & $2.96 \pm 0.02^{\mathrm{b}}$ & 21 & $3.21 \pm 0.02^{\mathrm{a}}$ & 0.002 \\
\hline & $\mathrm{G}_{1}$ & 34 & $2.85 \pm 0.05^{\mathrm{b}}$ & 16 & $2.95 \pm 0.06^{\mathrm{a}}$ & 0.048 \\
\hline & All samples & 63 & $2.90 \pm 0.03^{b}$ & 37 & $3.08 \pm 0.03^{a}$ & 0.038 \\
\hline \multirow[t]{3}{*}{ Protein yield (kg) } & $\mathrm{G}_{0}$ & 29 & $123.34 \pm 6.81$ & 21 & $110.49 \pm 9.00$ & 0.251 \\
\hline & $\mathrm{G}_{1}$ & 34 & $114.09 \pm 6.55$ & 16 & $122.17 \pm 10.68$ & 0.505 \\
\hline & All samples & 63 & $118.35 \pm 4.72$ & 37 & $115.54 \pm 6.86$ & 0.729 \\
\hline
\end{tabular}

FASN=Fatty acid synthase, $n=$ The number of samples, $Y=$ Average value, $S E M=$ Standard error of the mean, $G_{0}=0^{\text {th }}$ generation, $G_{1}=1^{\text {st }}$ generation, All samples=Both $G_{0}$ and $G_{1}$. abValues with different superscripts letters within the same rows differ significantly $(p<0.05)$

Table-4: Association of LOC514211 rs42688595 with milk traits.

\begin{tabular}{|c|c|c|c|c|c|c|c|c|}
\hline \multirow[t]{3}{*}{ Parameter } & \multirow[t]{3}{*}{ Generation } & \multicolumn{6}{|c|}{ Genotype } & \multirow[t]{3}{*}{ p-value } \\
\hline & & \multicolumn{2}{|r|}{ AA } & \multicolumn{2}{|r|}{ AC } & \multicolumn{2}{|r|}{ CC } & \\
\hline & & $\mathbf{n}$ & $\overline{\mathbf{Y}} \pm$ SEM & $\mathbf{n}$ & $\bar{Y} \pm$ SEM & $\mathbf{n}$ & $\overline{\mathbf{Y}} \pm$ SEM & \\
\hline \multirow[t]{3}{*}{ Milk yield (x1000 kg) } & $\mathrm{G}_{0}$ & 19 & $4.28 \pm 0.27$ & 10 & $3.58 \pm 0.38$ & 21 & $3.82 \pm 0.31$ & 0.337 \\
\hline & $\mathrm{G}_{1}$ & 20 & $4.17 \pm 0.34$ & 9 & $4.62 \pm 0.46$ & 21 & $3.79 \pm 0.27$ & 0.287 \\
\hline & All samples & 39 & $4.22 \pm 0.22$ & 19 & $4.07 \pm 0.31$ & 42 & $3.39 \pm 0.20$ & 0.373 \\
\hline \multirow[t]{3}{*}{ Fat $(\%)$} & $\mathrm{G}_{0}$ & 19 & $4.43 \pm 0.16$ & 10 & $4.52 \pm 0.15$ & 21 & $4.56 \pm 0.11$ & 0.787 \\
\hline & $\mathrm{G}_{1}$ & 20 & $3.63 \pm 0.12$ & 9 & $3.92 \pm 0.14$ & 21 & $3.92 \pm 0.16$ & 0.268 \\
\hline & All samples & 39 & $4.02 \pm 0.12$ & 19 & $4.24 \pm 0.12$ & 42 & $4.24 \pm 0.11$ & 0.304 \\
\hline \multirow[t]{3}{*}{ Fat yield (kg) } & $\mathrm{G}_{0}$ & 19 & $188.67 \pm 13.40$ & 10 & $161.87 \pm 17.51$ & 21 & $170.75 \pm 13.08$ & 0.446 \\
\hline & $\mathrm{G}_{1}$ & 20 & $152.15 \pm 13.95$ & 9 & $176.70 \pm 14.89$ & 21 & $146.28 \pm 10.41$ & 0.364 \\
\hline & All samples & 39 & $169.94 \pm 10.00$ & 19 & $168.90 \pm 11.42$ & 42 & $158.51 \pm 8.47$ & 0.632 \\
\hline \multirow[t]{3}{*}{ Protein (\%) } & $\mathrm{G}_{0}$ & 19 & $3.00 \pm 0.03$ & 10 & $3.00 \pm 0.06$ & 21 & $2.99 \pm 0.02$ & 0.844 \\
\hline & $\mathrm{G}_{1}$ & 20 & $2.83 \pm 0.06$ & 9 & $2.91 \pm 0.10$ & 21 & $2.89 \pm 0.06$ & 0.695 \\
\hline & All samples & 39 & $2.92 \pm 0.03$ & 19 & $2.96 \pm 0.06$ & 42 & $2.94 \pm 0.03$ & 0.773 \\
\hline \multirow[t]{3}{*}{ Protein yield $(\mathrm{kg})$} & $\mathrm{G}_{0}$ & 19 & $128.81 \pm 8.38$ & 10 & $132.72 \pm 11.30$ & 21 & $113.24 \pm 9.03$ & 0.281 \\
\hline & & 20 & $117.85 \pm 10.09$ & 9 & $133.03 \pm 12.43$ & 21 & $108.56 \pm 7.34$ & 0.168 \\
\hline & All samples & 39 & $123.19 \pm 6.56$ & 19 & $119.42 \pm 8.68$ & 42 & $110.90 \pm 5.76$ & 0.356 \\
\hline
\end{tabular}

$\mathrm{n}=$ The number of samples, $\mathrm{Y}=$ Average value, $S E M=$ Standard error of the mean, $\mathrm{G}_{0}=0^{\text {th }}$ generation, $\mathrm{G}_{1}=1^{\text {st }}$ generation, All samples $=$ Both $G_{0}$ and $G_{1}$. abValues with different superscripts letters within the same rows differ significantly $(p<0.05)$ 
Table-5: Association of FTO g. 1367A > T with milk traits.

\begin{tabular}{|c|c|c|c|c|c|c|c|c|}
\hline \multirow[t]{3}{*}{ Parameter } & \multirow[t]{3}{*}{ Generation } & \multicolumn{6}{|c|}{ Genotype } & \multirow[t]{3}{*}{ p-value } \\
\hline & & \multicolumn{2}{|r|}{ AA } & \multicolumn{2}{|r|}{ AT } & \multicolumn{2}{|r|}{ TT } & \\
\hline & & $\mathbf{n}$ & $\bar{Y} \pm$ SEM & $\mathbf{n}$ & $\bar{Y} \pm$ SEM & $\mathbf{n}$ & $\bar{Y} \pm$ SEM & \\
\hline \multirow{3}{*}{$\begin{array}{l}\text { Milk yield } \\
(x 1000 \mathrm{~kg})\end{array}$} & $\mathrm{G}_{0}$ & 36 & $4.06 \pm 0.21$ & 11 & $3.63 \pm 0.38$ & 3 & $4.37 \pm 0.07$ & 0.528 \\
\hline & $\mathrm{G}_{1}$ & 43 & $4.06 \pm 0.21$ & 4 & $4.46 \pm 0.95$ & 3 & $4.03 \pm 0.64$ & 0.862 \\
\hline & All samples & 79 & $4.06 \pm 0.15$ & 15 & $3.85 \pm 0.37$ & 6 & $4.20 \pm 0.30$ & 0.818 \\
\hline \multirow[t]{3}{*}{ Fat (\%) } & $\mathrm{G}_{0}$ & 36 & $4.48 \pm 0.10^{\mathrm{ab}}$ & 11 & $4.74 \pm 0.09^{a}$ & 3 & $3.92 \pm 0.40^{\mathrm{b}}$ & 0.049 \\
\hline & $\mathrm{G}_{1}$ & 43 & $3.84 \pm 0.09^{a b}$ & 4 & $4.41 \pm 0.19^{a}$ & 3 & $3.17 \pm 0.28^{\mathrm{b}}$ & 0.029 \\
\hline & All samples & 79 & $4.13 \pm 0.08^{\mathrm{ab}}$ & 15 & $4.52 \pm 0.15^{a}$ & 6 & $3.54 \pm 0.28^{\mathrm{b}}$ & 0.022 \\
\hline \multirow[t]{3}{*}{ Fat yield (kg) } & $\mathrm{G}_{0}$ & 36 & $179.04 \pm 9.86$ & 11 & $166.49 \pm 19.33$ & 3 & $170.72 \pm 15.10$ & 0.819 \\
\hline & $\mathrm{G}_{1}$ & 43 & $154.95 \pm 8.36$ & 4 & $166.39 \pm 29.50$ & 3 & $125.60 \pm 16.65$ & 0.597 \\
\hline & All samples & 79 & $165.93 \pm 6.50$ & 15 & $166.46 \pm 15.67$ & 6 & $148.16 \pm 14.24$ & 0.760 \\
\hline \multirow[t]{3}{*}{ Protein (\%) } & $\mathrm{G}_{0}$ & 36 & $2.99 \pm 0.02$ & 11 & $3.02 \pm 0.02$ & 3 & $2.94 \pm 0.08$ & 0.527 \\
\hline & $\mathrm{G}_{1}$ & 43 & $2.89 \pm 0.04$ & 4 & $2.80 \pm 0.10$ & 3 & $2.67 \pm 0.11$ & 0.270 \\
\hline & All samples & 79 & $2.94 \pm 0.03$ & 15 & $2.96 \pm 0.04$ & 6 & $2.81 \pm 0.09$ & 0.276 \\
\hline \multirow[t]{3}{*}{ Protein yield $(\mathrm{kg})$} & $\mathrm{G}_{0}$ & 36 & $120.50 \pm 6.53$ & 11 & $106.79 \pm 12.79$ & 3 & $128.08 \pm 2.13$ & 0.539 \\
\hline & $\mathrm{G}_{1}$ & 43 & $116.73 \pm 6.07$ & 4 & $123.78 \pm 25.95$ & 3 & $106.51 \pm 13.59$ & 0.854 \\
\hline & All samples & 79 & $118.45 \pm 4.42$ & 15 & $111.32 \pm 11.32$ & 6 & $117.30 \pm 7.82$ & 0.813 \\
\hline
\end{tabular}

FTO=Fat mass and obesity-associated, $\mathrm{Y}=$ Average value, SEM $=$ Standard error of the mean, $\mathrm{G}_{0}=0^{\text {th }}$ generation, $\mathrm{G}_{1}=1^{\text {st }}$ generation, All samples $=$ Both $\mathrm{G}_{0}$ and $\mathrm{G}_{1}$. ${ }^{\text {abValues }}$ with different superscripts letters within the same rows differ significantly $(p<0.05)$

Table-6: Comparison of milk traits between $\mathrm{G}_{0}$ and $\mathrm{G}_{1}$.

\begin{tabular}{lccc}
\hline Parameter & \multicolumn{2}{c}{ Generation $(\overline{\mathbf{Y}} \pm \mathbf{S E M})$} & p-value \\
\cline { 2 - 3 } & $\mathbf{G}_{\mathbf{0}}(\mathbf{n}=\mathbf{5 0})$ & $\mathbf{G}_{\mathbf{1}} \mathbf{( n = 5 0 )}$ & \\
\hline Milk yield $(\mathrm{N} 1000 \mathrm{~kg})$ & $3.94 \pm 0.18$ & $4.09 \pm 0.20$ & 0.588 \\
Fat $(\%)$ & $4.50 \pm 0.08^{\mathrm{a}}$ & $3.81 \pm 0.09^{\mathrm{b}}$ & $<0.001$ \\
Fat yield $(\mathrm{kg})$ & $175.78 \pm 8.24$ & $154.11 \pm 7.60$ & 0.054 \\
Protein $(\%)$ & $3.00 \pm 0.02^{\mathrm{a}}$ & $2.87 \pm 0.04^{\mathrm{b}}$ & 0.002 \\
Protein yield $(\mathrm{kg})$ & $117.94 \pm 5.48$ & $116.68 \pm 5.58$ & 0.872 \\
\hline
\end{tabular}

$\mathrm{Y}=$ Average value, $\mathrm{SEM}=$ Standard error of the mean, $\mathrm{n}=$ The number of samples, $\mathrm{G}_{0}=0^{\text {th }}$ generation, $\mathrm{G}_{1}=1^{\text {st }}$ generation ab Values with different superscripts letters within the same rows differ significantly $(p<0.05)$

were tested, and all were the GG genotype. According to An et al. [28], genotypes may not occur in a certain population because (1) individual performance was adversely affected by the missing genotype, and the animals with missing genotypes were excluded from the breeding process and (2) the missing genotype is rarer. Because the AA genotype was not found in $\mathrm{G}_{0}$ or the sire population, there was no AA genotype in $\mathrm{G}_{1}$, and the frequency of the A allele decreased. Therefore, the frequency of the GG genotype became higher in $\mathrm{G}_{1}$.

The order of the LOC514211 rs4268859 genotype frequencies from the highest to the lowest (CC, AA, and $\mathrm{AC}$ ) in this study was different from that reported by Anggraeni et al. [8] in Chinese Holstein cattle: AA (0.46), AC (0.33), and CC (0.21). The FTO g.1371T $>$ A AA genotype frequency of $0.72-0.86$ found in this study was much higher than that detected in Korean Hanwoo cattle (0.47) [13], but the lowest genotypic frequency (TT) was similar in both studies (0.13 vs. 0.08$)$.

The results of the studies mentioned above indicate that the allele frequencies observed in most studies of polymorphisms were specific for different cattle breeds or different cattle populations. Based on the expected versus observed genotype frequencies, LOC 514211 rs42688595 and FTO g.1371T>A were not in Hardy-Weinberg genetic equilibrium probably because of the limitation of the population size, the selection program for breeding, the mixing of the population with imported cows, and the migration of cows in BBPTUHPT Baturraden. According to Andrews [29], selection, non-random mating, and migration can cause changes in the frequency of certain genes, so one or more standard assumption for Hardy-Weinberg equilibrium might be broken.

\section{Association of the SNPs with milk traits}

The results of this study showed that the AG genotype of FASN rs41919985 resulted in a higher protein percentage than the GG genotype. No association of the SNP FASN rs41919985 with milk traits was found in Japanese Holstein cattle [10]. Different results, however, were reported by Barton et al. [27] and Schennink et al. [9], as they found that this SNP affected the level of milk yield, fatty acid composition, and milk fat percentage. The association of this SNP with milk protein percentage was not discussed in these studies; nevertheless, an association with milk protein yield has been reported [30].

The ruminant udder cannot immediately use acetyl-coenzyme A derived from glucose in mitochondria. The tricarboxylic acid cycle is only used to produce nicotinamide adenine dinucleotide phosphate hydrogen (NADPH). In the presence of NADPH, 
malonyl-coenzyme A and acetyl-coenzyme A are converted to palmitic acid. This process is catalyzed by FASN [27]. SNP rs41919985 is found on exon 39 of the FASN gene [26] and is a missense mutation that results in an amino acid change from threonine (ACC) to alanine (GCC). This mutation likely affects the structure of the substrate-binding site and therefore, may result in differences in enzymatic regulation and different milk compositions [26,27]. The FASN gene likely affects protein percentage through a pleiotropic action. Protein percentage is genetically positively correlated to the fat percentage with a moderate to high correlation coefficient $(0.16-0.55)$ [22]. The milk protein percentage can be improved by increasing the frequency of the $\mathrm{AG}$ genotype. Considering that a mating design where $\mathrm{AG}$ is crossed with $\mathrm{AG}$ will also produce the GG and AA genotypes, we recommend that the offspring with the GG genotype be culled from the population and that the AA genotype should be further studied to determine its association with milk traits.

The LOC514211 gene is an uncharacterized protein-coding gene [8]. The finding of no significant association for LOC 514211 rs42688595 in this study was not in line with those of previous genome-wide association studies based on 60k SNP-Chips [31] and PCR-RFLP in other populations [8], which found that this SNP affected milk and fat yield. The role of LOC514211 is not clear, and no previous study has explored the effect of the LOC514211 gene on milk traits.

At present, there are no available data on FTO g. 1371T $>A$ in dairy cattle in literature. However, this SNP has been studied in beef cattle (Hanwoo) [13], and the findings indicated that the AA genotype was correlated to a higher marbling score than the TT genotype. Similarly, in this study, the AT and AA genotypes correlated to a higher milk fat percentage than the TT genotype. In both studies, the TT genotype was rarely found, so it is not recommended for selection. If the TT genotype is ignored because of its low incidence and statistical testing are performed between only the AA and AT genotypes, cows with the AT genotype have significantly higher fat content than those with the AA genotype $(p=0.005)$, so we recommend the AT genotype for selection programs.

The FTO gene encodes Fe(II)-and 2-oxoglutarate-dependent dioxygenases. The FTO gene is the most abundant in the hypothalamus, which is the energy balance control center [14]. Polymorphic variations in FTO may affect fatty acid metabolism, demethylation catalysis of nucleic acids, energy homeostasis and energy partitioning regulation, and fat tissue development [32]. The mutations in LOC514211 rs42688595 $(\mathrm{CGA} \rightarrow \mathrm{AGA})$ and FTO g.1371T $>$ A $(\mathrm{CGU} \rightarrow \mathrm{CGA})$ are silent mutations that did not cause an amino acid change (in both cases, arginine is still produced). Although these are synonymous SNPs, they can influence gene function because synonymous SNPs may alter the structure, expression level, and function of proteins and affect mRNA splicing and stability [33].
Overall, the inconsistent results between our work and those of previous studies could be related to the background genes in the different breeds of cattle. $G_{1}$ showed a slightly higher milk yield $(4089 \mathrm{~kg})$ than $\mathrm{G}_{0}(3943 \mathrm{~kg})$, although this difference was not statistically significant. This increase in milk yield was the result of a selection program conducted at BBPTUHPT Baturraden, in which a certain proportion of the low-producing cows was culled. The lower fat and protein percentages of $G_{1}$ may be due to negative genetic correlations between milk yield and fat percentage and between milk yield and protein percentage ( $-0.3--0.5$, respectively) [34]. However, although $\mathrm{G}_{1}$ have significantly lower fat and protein percentages than $G_{0}$ the associations between the SNPs of the three candidate genes and observed traits were consistent in the $G_{0}$ and $G_{1}$ populations, reinforcing the evidence indicating that the effects of the genes on $\mathrm{G}_{0}$ are in line with their effects on $\mathrm{G}_{1}$.

\section{Conclusion}

The AG genotype of FASN rs41919985 and the AT genotype of FTOg.1371T $>$ A were associated with higher milk protein and fat percentages, respectively, whereas LOC514211 rs42688595 was not associated with any of the examined traits. These associations were consistent in the $\mathrm{G}_{0}$ and $\mathrm{G}_{1}$ populations. It can be concluded that the SNPs FASN rs41919985 and FTOg.1371T $>$ A can potentially be used as markers for the characteristics of milk protein and milk fat percentages, respectively.

\section{Authors' Contributions}

APR designed the experiment; performed data collection, DNA analysis, statistical analysis, and results in interpretation; and drafted the manuscript. $\mathrm{TH}, \mathrm{AP}$, and EK designed the experiment, supervised the fieldwork, interpreted the obtained results, and completed the critical revision of the manuscript. All authors read and approved the final manuscript.

\section{Acknowledgments}

This research was financed by LPDP (Indonesia Endowment Fund for Education) through the Doctoral Scholarship Program in 2016, grant number 20160222035511. The authors extend their gratitude to the head of BBPTUHPT Baturraden for allowing the study and the chief of the Laboratory of Animal Breeding and Genetics Universitas Gadjah Mada for performing the DNA analysis.

\section{Competing Interests}

The authors declare that they have no competing interests.

\section{Publisher's Note}

Veterinary World remains neutral with regard to jurisdictional claims in published institutional affiliation. 


\section{References}

1. Liu, Y., Liao, J., Ku, T., Li, X. and Sheppard, A.M. (2018) Assessment of milk quality using novel mutations of B2M gene in bovine DNA from milk. CyTA J. Food, 16(1): 281-286.

2. Rahayu, A.P., Kurnianto, E. and Johari, S. (2015) Genetic gains of milk yield and milk composition as realized response to dairy cow selection in BBPTU-HPT Baturraden, Indonesia. J. Indonesian Trop. Anim. Agric., 40(2): 79-86.

3. De Mello, F., Kern, E.L. and Bertoli, C.D. (2014) Progress in dairy cattle selection. Adv. Dairy Res., 2(1): 1-2.

4. Schaeffer, L.R. (2006) Strategy for applying genome-wide selection in dairy cattle. J. Anim. Breed. Genet., 123(4): 218-223.

5. Al-Samarai, F.R. and Al-Kazaz, A.A. (2015) Applications of molecular markers in animal breeding review. Am. J. Appl. Sci. Res., 1(1): 1-5.

6. Ordovás, L., Rosa, R., Pampín, S., Zaragoza, P., Osta, R., Rodr1'guez-Rey, J.C. and Rodellar, C. (2008) The g.763G_C SNP of the bovine FASN gene affects its promoter activity via Sp-mediated regulation: Implications for the bovine lactating mammary gland. Physiol. Genomics, 34(2): 144-148.

7. Zielke, L.G., Bortfeldt, R.H., Reissmann, M., Tetens, J., Thaller, G. and Brockmann, G.A. (2013) Impact of variation at the FTO locus on milk fat yield in Holstein dairy cattle. PLoS One, 8(5): e63406.

8. Anggraeni, A.S., Kurnianto, E., Johari, S., Sutopo, S. and Shujun, Z. (2015) Milk production and reproductive trait caused by LOC514211 gene mutation in dairy cows. J. Indonesian Trop. Anim. Agric., 40(4): 191-198.

9. Schennink, A., Bovenhuis, H., Leon-Kloosterziel, K.M., van Arendonk, J.A. and Visker, M.H. (2009) Effect of polymorphisms in the FASN, OLR1, PPARGC1A, PRL and STAT5A genes on bovine milk-fat composition. Anim. Genet., 40(6): 909-916.

10. Matsumoto, H., Inada, S., Kobayashi, E., Abe, T., Hasebe, H., Sasazaki, S., Oyama, K. and Mannen, H. (2012) Identification of SNPs in the FASN gene and their effect on fatty acid milk composition in Holstein cattle. Livest. Sci., 144(3): 281-284.

11. Zhao, X., Yang, Y., Sun, B.F., Zhao, Y.L. and Yang, Y.G. (2014) FTO and obesity: Mechanisms of association. Curr. Diab. Rep., 14(5): 486.

12. Ehrlich, A.C. and Friedenberg, F.K. (2016) Genetic associations of obesity: The fat-mass and obesity-associated (FTO) gene. Clin. Transl. Gastroenterol., 7(1): e140.

13. Chung, E.R. (2014) Novel SNP in the coding region of the FTO gene is associated with marbling score in hanwoo (Korean cattle). Anim. Sci. Technol., 56(1): 27-32.

14. Jevsinek, S.D., Kunej, T., Kovac, M., Malovrh, S., Potocnik, K., Petric, N., Zgur, S., Dovc, P. and Horvat, S. (2016) FTO gene variants are associated with growth and carcass traits in cattle. Anim. Genet., 47(2): 219-222.

15. Maylinda, S. (2011) Genetic polymorphism of growth hormone locus and its association with body weight in Grati dairy cows. Int. J. Biotechnol. Mol. Biol. Res., 2(7): 117-120.

16. Hartatik, T., Kurniawati, D. and Adiarto, A. (2015) Associations between polymorphism of growth hormone gene with milk production, fat and protein in content in Friesian Holstein cattle. J. Indonesian Trop. Anim. Agric., 40(3): 133-137.

17. Agung, P.P. and Laoditta, F. (2018) Identification of KLF3 gene polymorphism in Indonesian Friesian Holstein cattle. J. Indones. Trop. Anim. Agric., 43(3): 195-200.

18. Li, C., Sun, D., Zhang, S., Yang, S., Alim, M.A., Zhang, Q., Li, Y. and Liu, L. (2016) Genetic effects of FASN, PPARGC1A, ABCG2 and IGF1 revealing the association with milk fatty acids in a Chinese Holstein cattle population based on a post genome-wide association study. BMC Genet., 17(1): 110.

19. Bhaladhare, A., Sharma, D., Kumar, A., Sonwane, A., Chauhan, A., Singh, R., Kumar, P., Yadav, R., Baqir, M., Bhushan, B. and Prakash, O. (2016) Single nucleotide polymorphisms in toll-like receptor genes and case-control association studies with bovine tuberculosis. Vet. World, 9(5): 458-464.

20. Bhat, S., Kumar, P., Kashyap, N., Deshmukh, B., Dige, M.S., Bhushan, B., Chauhan, A., Kumar, A. and Singh, G. (2016) Effect of heat shock protein 70 polymorphism on thermotolerance in Tharparkar cattle. Vet. World, 9(2): 113-117.

21. Jain, V., Patel, B., Umar, F.P., Ajithakumar, H.M., Gurjar, S.K., Gupta, I.D. and Verma, A. (2017) Identification of single nucleotide polymorphism in protein phosphatase 1 regulatory subunit 11 gene in Murrah bulls. Vet. World, 10(2): 244-248.

22. Petrini, J., Iung, L.H.S., Rodriguez, M.A.P., Salvian, M., Pertille, F., Rovadoscki, G.A., Coutinho, L.L., Machado, P.F., Wiggans, G.R. and Mourão, G.B. (2016) Genetic parameters for milk fatty acids, milk yield and quality traits of a Holstein cattle population reared under tropical conditions. J. Anim. Breed. Genet., 133(5): 384-395.

23. Santosa, S.A., Sudewo, A.T.A. and Susanto, A. (2014) Creating milk production correction factors of dairy cattle. J. Agripet, 14(1): 1-5.

24. Vanvleck, L.D. and Barr, G.R. (1963) Genotype and variability in dairy lactation records. Genetics, 48(11): 1441-1443.

25. Mulder, H.A., Bijma, P. and Hill, W.G. (2007) Prediction of breeding values and selection responses with genetic heterogeneity of environmental variance. Genetics, 175(4): 1895-1910

26. Oztabak, K., Gursel, F.E., Akis, I., Ates, A., Yardibi, H. and Turkay, G. (2014) FASN gene polymorphism in indigenous cattle breeds of Turkey. Folia Biol. (Kraków), 62(1): 29-35.

27. Bartoň, L., Bureš, D., Kott, T. and Řehák, D. (2016) Associations of polymorphisms in bovine DGAT1, FABP4, FASN, and PPARGC1A genes with intramuscular fat content and the fatty acid composition of muscle and subcutaneous fat in Fleckvieh bulls. Meat Sci., 114(1): 18-23.

28. An, X.P., Hou, J.X., Zhao, H.B., Bai, L., Peng, J.Y., Zhu, C.M., Yan, Q.M., Song, Y.X., Wang, J.G. and Cao, B.Y. (2013) Polymorphism identification in goat DGAT1 and STAT5A genes and association with milk production traits. Czech J. Anim. Sci., 58(7): 321-327.

29. Andrews, C. (2010) The hardy-Weinberg principle. Nat. Educ. Knowl., 3(10): 65.

30. Ciecierska, D., Frost, A., Grzesiak, W., Proskura, W.S., Dybus, A. and Olszewski, A. (2013) The influence of fatty acid synthase polymorphism on milk production traits in Polish Holstein-Friesian cattle. J. Anim. Plant. Sci., 23(2): 376-379.

31. Junjing, W. (2012) Genome-Wide Association Study of Reproduction and Milk Production Traits in Dairy Cows and Water Buffalo. Ph.D. Thesis, Huazhong Agricultural University, China.

32. Wei, S., Zan, L., Ujan, J.A., Wang, H., Yang, Y. and Adoligbe, C. (2011) Novel polymorphism of the bovine fat mass and obesity-associated (FTO) gene are related to backfat thickness and longissimus muscle area in five Chinese native cattle breeds. Afr. J. Biotechnol., 10(15): 2820-2824.

33. Hunt, R., Sauna, Z.E., Ambudkar, S.V., Gottesman, M.M. and Kimchi-Sarfaty, C. (2009) Silent (synonymous) SNPs: Should we care about them. Methods Mol. Biol., 578(4): 23-39.

34. Toghiani, S. (2012) Genetic relationships between production traits and reproductive performance in Holstein dairy cows. Arch. Tierzucht., 55(5): 458-468. 